\title{
Asymptomatic Charcot Foot in Longstanding Diabetes
}

\author{
MOHAMED E. EL-SHINAWI, M.D.; NADER M. HAMADA, M.D. and \\ ABDEL RAHMAN M. ABDEL RAHMAN, M.Sc. \\ The Department of General Surgery, Faculty of Medicine, Ain Shams University
}

\begin{abstract}
Background: Charcot foot is a longstanding complication of Diabetes Mellitus (DM) and the incidence of undiagnosed Charcot disease among diabetic patients ranges from $0.4 \%$ to $13 \%$.

Aim of Study: This study aimstodiagnose preclinical Charcot disease in longstanding diabetic patients.

Patients and Methods: Aprospective study was carried out on 50 patients with longstanding diabetes. Full history was taken, laboratory and radiological investigations were performed.

Results: $52 \%$ of patients were found to have positive findings for Charcot disease. Positive findings on X-ray were found to be significantly related with age, $\mathrm{HbA}{ }_{1 \mathrm{C}}$, $\mathrm{DM}$ duration and body mass index.

Conclusion: Patients with long standing diabetes mellitus with no obvious deformity or foot ulcerations should be screened for Charcot foot X-ray findings and should be advised about proper glycemic control, avoiding minor trauma and seeking medical advice once early clinical signs of Charcot foot appear.
\end{abstract}

Key Words: Charcot foot - Long standing diabetes - X-Ray.

\section{Introduction}

CHARCOT neuropathic osteoarthropathy, commonly referred to as, the Charcot foot is a longstanding complication of diabetes mellitus. It affects bone joints and soft tissues of the foot and ankle [1].Peripheral neuropathy is its underlying cause andits most common etiology is diabetes mellitus

There are specific X-ray findings of Charcot foot, the early detection of which plays an important role in early diagnosis of Charcot disease and minimizing its serious complications [3].

Correspondence to: Dr. Mohamed E. El-Shinawi, The Department of General Surgery, Faculty of Medicine, Ain Shams University.
This study was conducted todiagnose preclinical Charcot disease in longstanding diabetic patients aiming to reduce its complications.

\section{Patients and Methods}

Study design and time frame:

This study was a prospective cohort study that was carried out on patients with longstanding diabetes mellitus who attended for follow-up during the period from the beginning of September 2019 till March 2020 in in Ain Shams University Hospitals and Sheikh Zayed Specialized Hospital.

\section{Patients:}

Fifty patients with longstanding diabetes, fulfilling inclusion and exclusion criteria, were included in the study.

Inclusion criteria: Diabetic patients who were aged 18 years or above and had longstanding diabetes (more than 10 years).

Exclusion criteria: Diabetic children below 18 years old; patients with previous history of Charcot foot; patients with any cause of peripheral neuropathy other than diabetes mellitus; patients currently having any type of foot ulcers including ischemic, neuropathic, traumatic and venous ulcers or who had pervious minor or major amputations; patients with peripheral arterial diseases and patients with current or history of peripheral vascular disease or previous angioplasty or arterial bypass and patients with absent dorsalis pedis artery and posterior tibial artery pulsations were excluded from the study.

\section{Methods:}

History taking: Full history was taken from all enrolled patients and included gender; age; diabetic history (type and duration of DM, diabetic control, 
hypoglycaemic medications, longstanding complications of DM including diabetic retinopathy and diabeticnephropathy); symptoms of peripheral neuropathy (gradual onset of numbness, prickling or tingling in feet or hands which can spread upwards into legs andarms; sharp, jabbing, throbbing or burningpain; untrue feeling of wearing gloves orsocks; paralysis if motor nerves areaffected; heat intolerance; excessive sweating or inability tosweat; bowel, bladder or digestive problems in cases of autonomic neuropathy); past medical history (hypertension, coronary artery disease, cardiomyopathy, congestive heart failure, cerebrovascularaccident) and history of lower limb surgeries.

Clinical examination: General examination, including Body Mass Index (BMI) and local examination which included.

Arterial assessment: Patients were examined for skin temperature, capillary refilling time, ischemic or trophic changes and peripheral arterial pulsations of both dorsalis pedis artery and posterior tibial artery of both feet and patients who had peripheral arterial disease were excluded.

Neurological assessment: Patients were assessed to diagnose peripheral neuropathy including assessment of peripheral sensations, gait and coordination, muscle power and reflexes (deep ankle reflex and ankle jerk reflex).

Oedema assessment: Patients of the study were assessed for oedema. Mild oedema was considered when there was $2 \mathrm{~mm}$ skin depression that disappears rapidly; moderate oedema was considered when there was $4 \mathrm{~mm}$ skin depression that disappears within 10-15 seconds; moderately severe oedema was considered when there was $6 \mathrm{~mm}$ skin depression that lasts more than one minute and severe oedema was considered when there was 8 mm skin depression that lasts more than two minutes.

Investigations: Were performed for all patients and included laboratory (complete blood count 'CBC' and haemoglobin $\mathrm{A} 1_{\mathrm{c}}$ ) and radiological investigations.

All patients included in the study had bilateral plain foot X-ray by both Stephani X and Apollo devices in both Antero-Posterior (AP) and oblique views. The AP view examines phalanges, metatarsals and tarsal bones in which the patient may be supine or upright depending on comfort and the affected leg must be flexed enough that the plantar aspect of the foot is resting on the image receptor, in this view $1^{\text {st }}$ metatarsal has even concavity, the spaces between the 2 nd to 5 th metatarsal are equal, yet the bases are overlapping and inter-tarsal space between the medial and intermediate cuneiform should be open. The oblique view examines phalanges, metatarsals and tarsal bones in which the patient may be supine or upright depending on comfort, the affected leg must be flexed enough that the plantar aspect of the foot is resting on the image receptor and the foot is medially rotated until the planter surface sits at a $45^{\circ}$ angle to the image receptor, in this view superimposition is evident at the bases of the of 1 st and 2 nd metatarsals, there is no superimposition of the 3 rd to 5 th metatarsal, base of the 5 th metatarsal is free of superimposition from any structure, tarsal sinus (a cylindrical cavity located between the talus and calcaneus on the lateral aspect of the foot) is visible, joint spaces around the cuboidareopen and equal and cuboid is free of superimposition. Radiographs which did not fulfill the previous criteria were repeated.

Feet X-rays were assessed by the radiology department to identify early signs of Charcot foot in the plain foot X-rays which include: Focal bone demineralization; debris formation at the articular margin; fragmentation of subchondral bone; capsular distention; subluxation, dislocation and particular fractures. All cases with X-ray changes (which were mostly focal bone demineralization, fragmentation of subchondral bone, debris formation at articular surface and capsular distention) were advised about weight reduction, proper glycemic control, avoiding minor trauma and were followed-up by 6-months X-rays. While patients whose X-rays showed no changes were advised about weight reduction, proper glycemic control, avoiding minor trauma and were instructed about seeking medical advice once early Charcot foot symptoms (erythema, swelling, mild pain) appear to avoid misdiagnosis with similar conditions, progression of the disease and foot deformity.

\section{Statistical analysis:}

Data were collected, revised, coded, tabulated and analyzed using the Statistical Package for Social Science (IBM SPSS) version 21. Quantitative data were presented as mean, standard deviations and ranges. Meanwhile, qualitative variables were presented as number and percentages. The appropriate tests of significance were conducted. The confidence interval was set to $95 \%$ and the margin of error accepted was set to $5 \%$. So, the $p$ value was considered significant at the level of $<0.05$. 


\section{Results}

The study included 50 diabetic patients with longstanding type II diabetes mellitus and showed peripheral neuropathy (in the form of loss of pain and temperature sensations with preservation of light touch and vibration sensations, tested by monofilament and quantitative sensorytests). Their socio-demographic and clinical characters are shown in (Table 1), Fig. (1).

Table (1): Socio-demographic and clinical characters of the studied group.

\begin{tabular}{|c|c|}
\hline Parameters & $\begin{array}{l}\text { Study group } \\
\quad(\mathrm{n}=50)\end{array}$ \\
\hline $\begin{array}{l}\text { Age (years): } \\
\text { - Mean } \pm \mathrm{SD} \\
\text { - Median } \\
\text { - Range }\end{array}$ & $\begin{array}{l}58.44 \pm 7.3 \\
56 \\
48-75\end{array}$ \\
\hline $\begin{array}{l}\text { Gender: } \\
\text { - Male, n (\%) } \\
\text { - Female, n (\%) }\end{array}$ & $\begin{array}{l}30(60 \%) \\
20(40 \%)\end{array}$ \\
\hline $\begin{array}{l}\text { BMI: } \\
\text { - Mean } \pm \text { SD } \\
\text { - Median } \\
\text { - Range }\end{array}$ & $\begin{array}{l}28.34 \pm 4.049 \\
29 \\
19-35\end{array}$ \\
\hline $\begin{array}{l}\text { Duration of DM: } \\
\text { - Mean } \pm \mathrm{SD} \\
\text {-Median } \\
\text { - Range }\end{array}$ & $\begin{array}{l}14.36 \pm 4.14 \\
13.5 \\
10-25\end{array}$ \\
\hline $\begin{array}{l}H_{b A_{1}}: \\
\text { - Mean } \pm \mathrm{SD} \\
\text { - Median } \\
\text { - Range }\end{array}$ & $\begin{array}{l}8.11 \pm 0.95 \\
8.15 \\
6.8-10\end{array}$ \\
\hline $\begin{array}{l}\text { Type of diabetic medications: } \\
\text { - Insulin, } \mathrm{n}(\%) \\
\text { - Oral hypoglycemic, } \mathrm{n}(\%)\end{array}$ & $\begin{array}{l}29(58 \%) \\
21(42 \%)\end{array}$ \\
\hline $\begin{array}{l}\text { Associated comorbidities: } \\
\text { - HTN, n (\%) } \\
\text { - Hypertensive \& ischemic heart disease, n (\%) } \\
\text { - Diabetic nephropathy, n (\%) } \\
\text { - Ischemic heart disease, n }(\%) \\
\text { - Diabetic retinopathy, n }(\%) \\
\text { - DVT, n (\%) } \\
\text { - NO comorbidities, n }(\%)\end{array}$ & $\begin{array}{l}14(28 \%) \\
5(10 \%) \\
5(10 \%) \\
2(4 \%) \\
2(4 \%) \\
1(2 \%) \\
21(42 \%)\end{array}$ \\
\hline
\end{tabular}

Twenty six (52\%) of patients had positive findings for Charcot disease at presentation (Table 2). In the positive group, the X-ray studiesonbothfeetwithobliquelateralandantero-posteriorviews showed focal bone demineralization only in eight patients, focal bone demineralization with fragmentation of subchondral bone and mild dislocation in three cases, debris formation at the articular margin with fragmentation of subchondral bone and mild sublaxation in eight cases, capsular distention with fragmentation of subchondral bone and mild sublaxation in two patients and fragmentation of sub- chondral bone with debris formation at the articular margin in five patients. Also $78 \%$ of the changes were detected in antero-posterior view of X-rays while $22 \%$ of the changes were detected in oblique lateral view of X-rays. All these X-ray changes were found in one foot (unilateral involvement) and were found in the midfoot of $20(76.9 \%)$ patients and forefoot of six $(23.1 \%)$ patients (Table 3$)$.

Table (2): X-Ray findings at presentation and at six months follow-up.

\begin{tabular}{lllllll}
\hline \multirow{2}{*}{ Changes in X-ray } & \multicolumn{2}{c}{ Negative } & & \multicolumn{2}{c}{ Positive } & \multirow{2}{*}{ Total } \\
\cline { 2 - 3 } & $\mathrm{N}$ & $\%$ & & $\mathrm{~N}$ & $\%$ & $\mathrm{~N}$ \\
\hline - At presentation & 24 & 48 & & 26 & 52 & 50 \\
$\begin{array}{l}\text { - After 6 months (in } \\
\text { positive cases) }\end{array}$ & 21 & 80.77 & & 5 & 19.23 & 26 \\
\hline
\end{tabular}

Table (3): Site of Charcot disease in positive patients.

\begin{tabular}{lllllll}
\hline & \multicolumn{2}{c}{ Mid foot } & & \multicolumn{2}{c}{ Forefoot } & \multirow{2}{*}{ Total } \\
\cline { 2 - 3 } & $\mathrm{N}$ & $\%$ & & $\mathrm{~N}$ & $\%$ & $\mathrm{~N}$ \\
\hline Site at presentation & 20 & 76.9 & & 6 & 23.1 & 26 \\
After follow-up & 5 & 100 & & 0 & 0.0 & 5 \\
\hline
\end{tabular}

Positive findings on X-ray were found to be significantly related with increasing age $(p=0.024)$. There was statistically significant relation between finding positive changes on $\mathrm{X}$-ray with increase of $_{\mathrm{HbA1C}}(p<0.001)$ and DM duration $(p<0.001)$. Also, positive changes were significantly related to BMI increase $(p<0.001)$. On the other hand, there was no statistically significant relation between finding positive changes on X-ray with gender $(p=0.16)$ or type of diabetic medication $(p=$ 0.15 ) (Table 4).

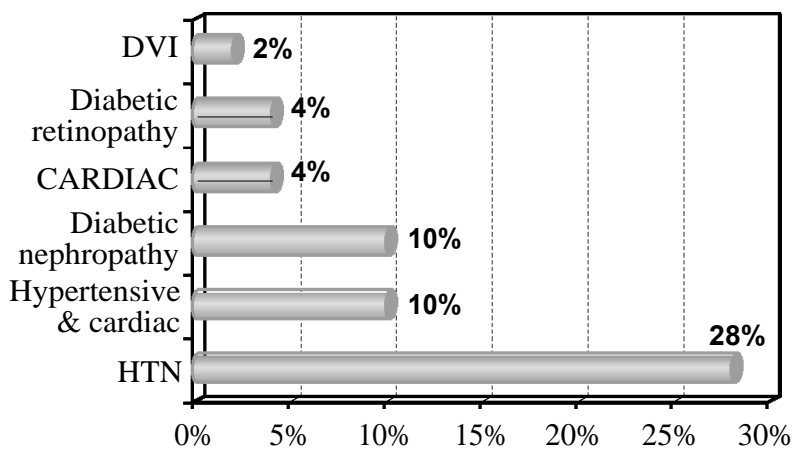

Fig. (1): Associated co-morbidities in the included patients.

\begin{tabular}{ll}
\hline Parameters & No. (\%) \\
\hline Associated comorbidities: & \\
HTN, n (\%) & $14(28 \%)$ \\
Hypertensive \& ischemic heart disease, n (\%) & $5(10 \%)$ \\
Diabetic nephropathy, n (\%) & $5(10 \%)$ \\
Ischemic heart disease, n (\%) & $2(4 \%)$ \\
Diabetic retinopathy, n (\%) & $2(4 \%)$ \\
DVT, n (\%) & $1(2 \%)$ \\
\hline
\end{tabular}


Table (4): Association between positive X-Ray findings and socio-demographic and clinical data.

\begin{tabular}{|c|c|c|c|}
\hline & $\begin{array}{l}\text { Positive } \\
\text { findings } \\
(n=26)\end{array}$ & $\begin{array}{l}\text { Negative } \\
\text { findings } \\
(\mathrm{n}=24)\end{array}$ & $\begin{array}{c}p- \\
\text { value }\end{array}$ \\
\hline $\begin{array}{l}\text { Age (years): } \\
\text { - Mean } \pm \mathrm{SD} \\
\text { - Median } \\
\text { - Range }\end{array}$ & $\begin{array}{l}61.29 \pm 7.8 \\
60 \\
48-75\end{array}$ & $\begin{array}{l}55.2 \pm 5.4 \\
55 \\
48-66\end{array}$ & $0.024^{*}$ \\
\hline $\begin{array}{l}\text { Gender: } \\
\text { - Male, n (\%) } \\
\text { - Female, n }(\%)\end{array}$ & $\begin{array}{l}13(50 \%) \\
13(50 \%)\end{array}$ & $\begin{array}{l}17(70.8 \%) \\
7 \quad(29.2 \%)\end{array}$ & $0.16 \dagger$ \\
\hline $\begin{array}{l}\text { Duration of DM: } \\
\text { - Mean } \pm \text { SD } \\
\text { - Median } \\
\text { - Range }\end{array}$ & $\begin{array}{l}17.59 \pm 3.99 \\
19 \\
10-25\end{array}$ & $\begin{array}{l}11.7 \pm 2.9 \\
10 \\
10-20\end{array}$ & $<0.001 *$ \\
\hline $\begin{array}{l}B M I\left(K g / m^{2}\right): \\
\cdot \text { Mean } \pm \mathrm{SD} \\
\cdot \text { Median } \\
\cdot \text { Range }\end{array}$ & $\begin{array}{l}31.18 \pm 1.85 \\
31 \\
28-35\end{array}$ & $\begin{array}{l}24.8 \pm 2.86 \\
25 \\
20-31\end{array}$ & $<0.001 *$ \\
\hline $\begin{array}{l}H b A 1 C: \\
\text { - Mean } \pm \text { SD } \\
\text { - Median } \\
\text { - Range }\end{array}$ & $\begin{array}{l}9.03 \pm 0.63 \\
8.8 \\
8.3-10\end{array}$ & $\begin{array}{l}7.23 \pm 0.19 \\
7.2 \\
6.8-7.5\end{array}$ & $<0.001 *$ \\
\hline $\begin{array}{l}\text { Medication of DM: } \\
\text { - Insulin, n (\%) } \\
\text { - Oral hypoglycemic, } \\
\text { n (\%) }\end{array}$ & $\begin{array}{l}18(69.2 \%) \\
8 \quad(30.8 \%)\end{array}$ & $\begin{array}{l}11(45.8 \%) \\
13(54.2 \%)\end{array}$ & $0.15 \dagger$ \\
\hline
\end{tabular}

*: Analysis by independent-samples Mann-Whitney U-test. $\dagger$ : Analysis by Fisher's Exact test.

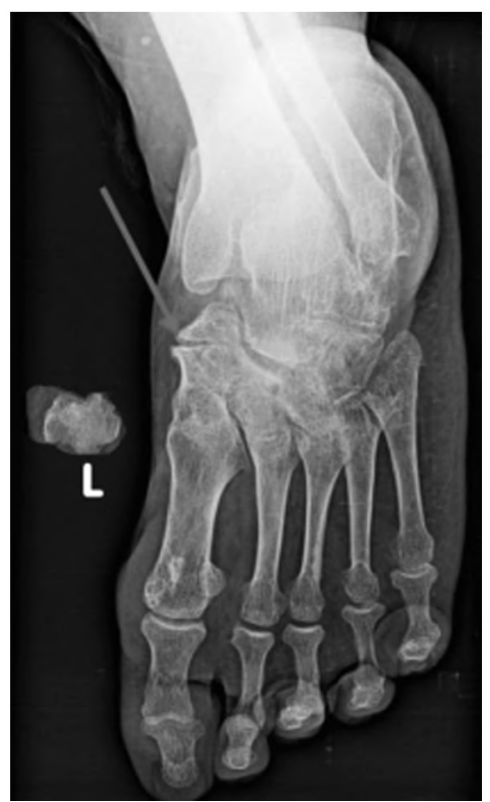

Fig. (2): X-ray of case (1) (antero-posterior view) at presentation shows avascular necrosis of navicular bone.

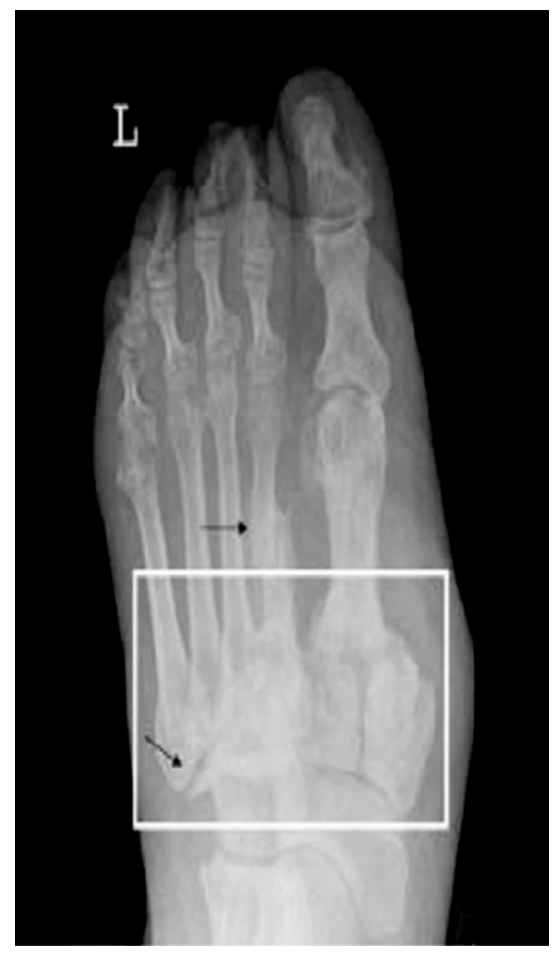

Fig. (3): X-ray at 6 months of case (1) (antero-posterior view) shows disorganized tarsometatarsal (TMT) joints (white box) and fractures of metatarsal (MTT) II and $\mathrm{V}$ (black arrows) in the midfoot region.

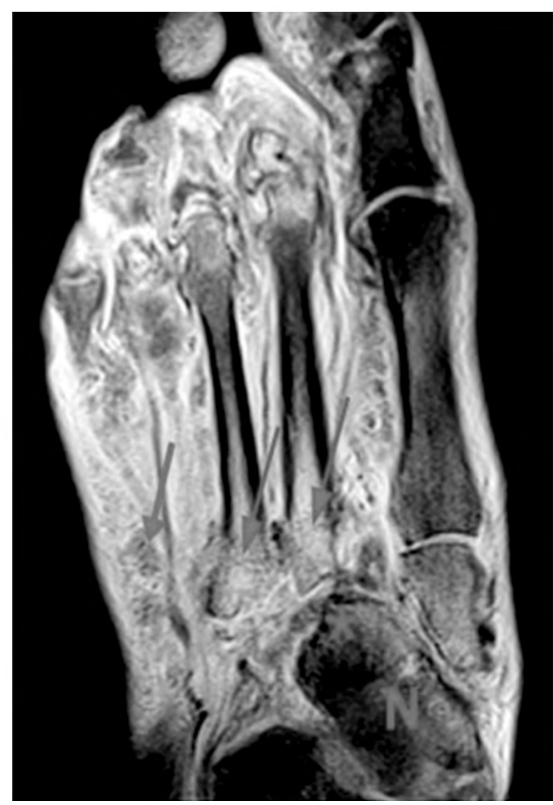

Fig. (4): MRI of case (1) shows lateral subluxation and fragmentation of the second, third and $5^{\text {th }}$ metatarsal bases with diffuse marrow edema (arrows). The navicular $(\mathrm{N})$ is rotated such that its lateral cortex articulates with the second metatarsal base (asterisk), and its distal cortex with the medial cuneiform. There is also marrow edema and cortical irregularity at the metatarsal-phalangeal joints. Diffuse soft tissue edema is present. 


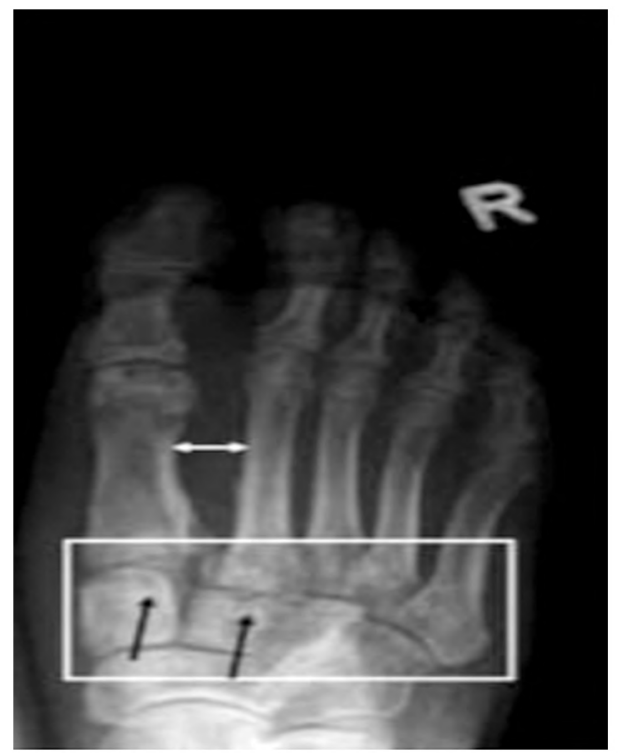

Fig. (5): X-ray at presentation of case (2) (antero-posterior view) shows osteopenia (white box), cartilage fragmentation of the tarsometatarsal (TMT) joint I and II and cuneiform I and II bones (black arrows). There is an increased joint space between metatarsal bone I and II (white arrow) indicating Lisfranc's joint dislocation with lateral displacement of the metatarsal (MTT) bones.

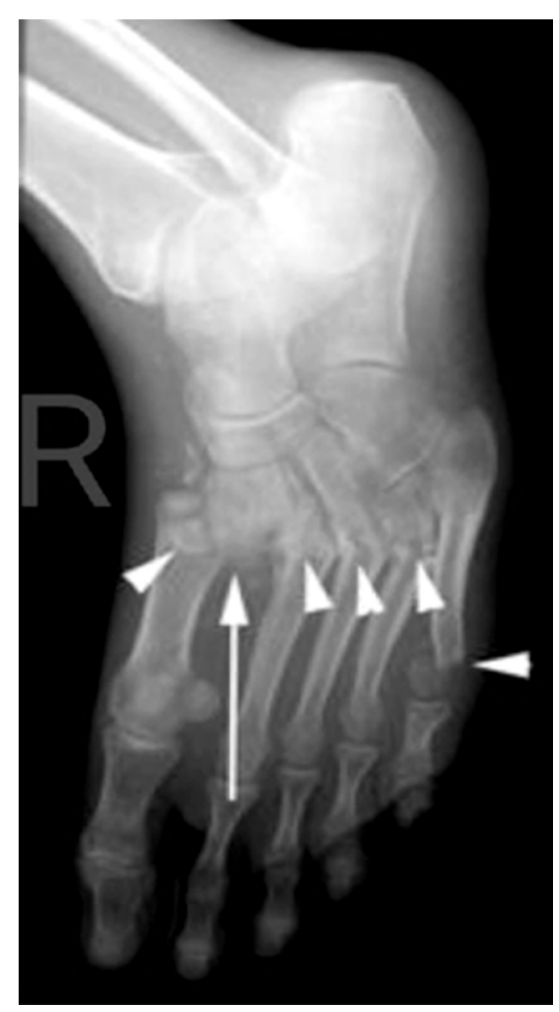

Fig. (6): X-ray at 6 months of case (2) (oblique lateral view) shows several fractures (arrowheads) and a dislocation of the first metatarsal bone (arrow).

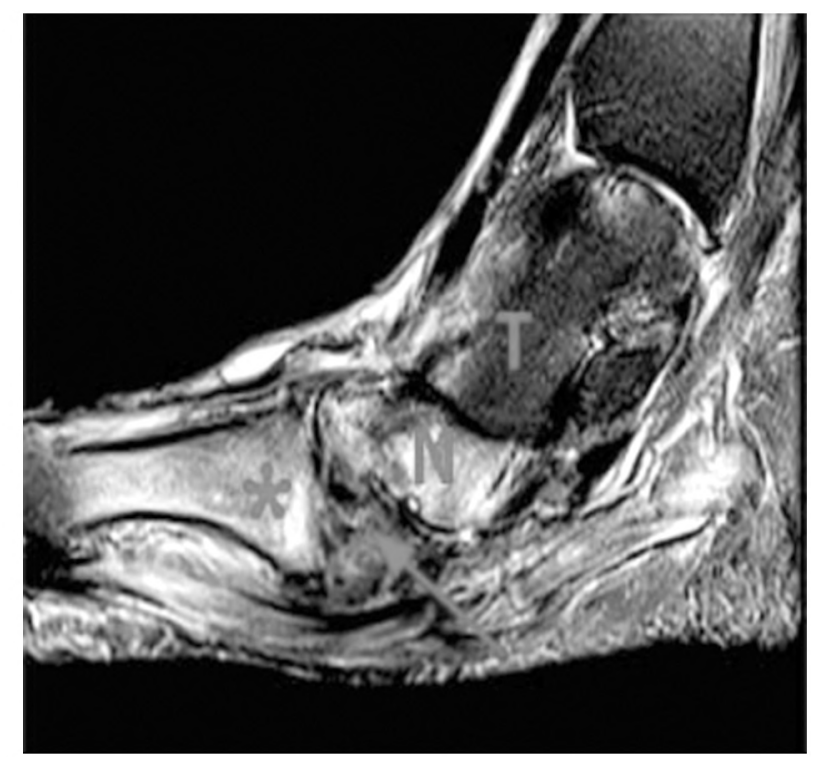

Fig. (7): MRI of case (2) demonstrates disruption of the longitudinal arch of the foot, with plantar flexion of the talus (T) and navicular $(\mathrm{N})$, and relative dorsal subluxation of the first metatarsal (asterisk). A fracture of the medial cuneiform (arrow) is also present.

\section{Discussion}

The prevalence of Charcot foot in a general diabetic population is estimated between 0.1 and $7.5 \%$. However, many cases are likely undiagnosed due to a lack of recognition of the typical presentation and the often asymptomatic nature of the condition. Some studies reported that the incidence of undiagnosed Charcot disease among diabetic patients ranges from $0.4 \%$ to $13 \%$ [3-5]

Early detection X-ray findings of Charcot footcould play an important role in early diagnosis of Charcot disease and appropriate management may prevent the progression of foot deformity and serious complications of the disease [6,7]

The mean patients' age in the positive group in the present study was $61.29 \pm 7.8$ years while the main age in the negative group was $55.2 \pm 5.4$ years. A higher mean age in the positive group was reported by Smith et al., [8] who evaluated foot deformities in 456 diabetic patients with a mean age of 63.7 years. However, our mean age in positive group is lower than that of Wanzou et al., [9] who performed a cross-sectional study in Uganda on 100 diabetic patientswith a mean age of 51.3 years. The variations in age could be attributed to 
different inclusion criteria; Smith et al., [8] included patients with previous amputations, which is associated with older age, while Wanzou et al., [9] included patients with DM of more than 7 years, compared with 10 years in our study.

The association between patients' age and the development of Charcot foot has been investigated in a number of studies. A significant association was found between Charcot foot and older age [10] Meanwhile, Wanzou et al., [9] reported no significant association between patients' age and Charcot foot.

In the positive group of the present study, 50\% of patients were males while in the negative group $70.8 \%$ of patients were males. Several studies reported the absence of gender predilection in diabetic patients with Charcot foot [11-13]. However, some studies showed that male gender is a risk factorfor developing Charcot foot. Salini et al., [14] study retrospectively reviewed medical records of 1475 Indian patients with T2DM and severe peripheral neuropathy and reported ahigher prevalence of Charcot foot among males. Similarly, higher frequency Charcot foot among male patients was reported in other studies $[\mathbf{8 , 1 0 , 1 5 - 1 7 ]}$. The higher rates in males may be attributed to the increased physical activity and manual work in males compared to females. In addition, the level of self-care could be much better in females than males [14] However, other studies reported ahigher prevalence of Charcot foot among females $[\mathbf{9 , 1 8 , 1 9 ]}$.

In the present study, the mean patients' Body Mass Index (BMI) in the positive group was 31.18 \pm 1.85 , while in the negative group the mean BMI was $24.8 \pm 2.86$. Our results are higher than results of Wanzou et al., [9] study, in which the mean BMI of diabetic patients was 27.6.

Other studies reported the BMI of diabetic patients with Charcot foot with comparable findings to our results. In Thewjitcharoen et al., [19] study on 40 cases of diabetic Charcot foot, the BMI was 28.2. In Sebastian et al., [20], the mean BMI was 29.2. However, Nehring et al., [10] reported a higher mean patients' BMI of 32.8, while Younis et al., [13] reported a lower mean patients' BMI of 23.3. A significant association was previously reported between Charcot foot and higher BMI $[10,20]$ However, other studies demonstrated no significant association $[9,13]$

Positive group patients in our study had a mean duration of diabetes of $17.59 \pm 3.99$ years, ranging from 10-25 years, while in the negative group the mean duration of diabetes mellitus was $11.7 \pm 2.9$ years ranging from 10-20 years.

Most patients with diabetic Charcot foot have been reported to have diabetes mellitus for at least 10 years $[\mathbf{3 , 2 1}]$. And several studies reported a significant association between Charcot foot and the duration of DM $[9,10,13,18]$

In the present study, the mean patients' $\mathrm{HbA}_{1 \mathrm{c}}$ level in the positive group was $9.03 \pm 0.63 \%$, ranging from 8.3 to 10 , which indicates suboptimal glycemic control, while in the negative group the mean $\mathrm{HbA}_{1 \mathrm{c}}$ level was $7.23 \pm 0.19$ ranging from 6.8 to 7.5. Our results are close to that of Chantelau \& Poll [12] study with a mean $\mathrm{HbA}_{1 \mathrm{c}}$ level of $8.6 \%$.

Some studies included patients with higher $\mathrm{HbA}_{1 \mathrm{c}}\left[\mathbf{1 1 , 1 3 , 1 9 ]}\right.$. However, lower $\mathrm{HbA}_{1 \mathrm{c}}$ levels were reported in other studies $[\mathbf{9 , 1 5}]$

Hyperglycemia may lead to an imbalance between osteoclasts and osteoblasts activity, promoting bone tissue changes [22]. The association between Charcot foot and glycemic control has been investigated in a number of studies. Many studies reported a significant association of Charcot foot with poor glycemic control [20,23]. Other studies didnot find a significant association [9]

In the present study, $69.2 \%$ of patients in the positive group were on insulin therapy while $30.8 \%$ were on oral hypoglycemic drugs, while in the negative group $45.8 \%$ of patients were on insulin and $54.2 \%$ were on oral hypoglycemic medications. A higher percentage of patients were on insulin therapy in previous studies $[\mathbf{1 2 , 1 8 ]}$.

In the present study, $42 \%$ of patients had no other associated comorbidities. However, $28 \%$ of patients had hypertension, $4 \%$ had cardiac problems, $10 \%$ had hypertension with cardiac problems, $10 \%$ had diabetic nephropathy, $4 \%$ had retinopathy, and $2 \%$ had DVT. Comorbid conditions have been frequently reported in previous studies. In Nehring et al., [10] study, $51.5 \%$ of patients had hypertension, $21.2 \%$ had ischemic heart disease, and $18.2 \%$ had renal failure. In Kensarah et al., [17] study, 46.3\% of patients had nephropathy, $59.4 \%$ had retinopathy, $48.4 \%$ had cardiomyopathy, and $83.8 \%$ had hypertension. In O'Loughlin et al., [15] study, $43 \%$ of patients had nephropathy, $18 \%$ had coronary artery disease, $2 \%$ had peripheral vascular diseases, and $5 \%$ had a history of cerebrovascular accidents. In Thewjitcharoen et al., [19] study, 59.1\% of patients had diabetic retinopathy, $48.6 \%$ had chronic kidney diseases, and $2.5 \%$ had ischemic heart diseases. In Sebastian et al., [20] study, $70 \%$ of patients had 
hypertension and 30\% had nephropathy. Significant associations have been demonstrated between Charcot foot, hypertension and renal failure [23,24]

In the present study, $52 \%$ of patients had Xray findings of Charcot foot. All these X-ray changes were unilateral and were found in mid-foot of $76.9 \%$ of patients and forefoot of $23.1 \%$ patients. $78 \%$ of these X-ray changes were found in anteroposterior view of X-ray while $22 \%$ were found in oblique lateral view of X-ray. In Wanzou et al., [9] study, $12 \%$ had Charcot foot. Fifty percent of the identified lesions were in the forefoot and $50 \%$ in the midfoot. In Smith et al., [8] study, radiography of 428 cases identified Charcot foot in $1.4 \%$ of cases, all of which had radiographic evidence of midfoot Charcot changes. In their study, they defined radio-graphic evidence of Charcot changes as the presence of atypical pattern of bone destruction and bone repair. In Fabrin et al., [11] study, 115 patients with Charcot foot were identified from 3000-5000 diabetic patients, with an estimated incidence of $0.3 \%$ per year. In this study, $93 \%$ of diabetic patients with Charcot foot had radiological evidence of osteoarthropathy (e.g., fragmentation and osteolysis of bones followed by new bone formation and ankylosis of the small joints involved).

Viswanathan et al., [25] study included 150 patients with T2DM, one-third of which had neuropathy and one-third had foot ulceration. Standardized dorsi-plantar and lateral weight-bearing radiographs identified Charcot foot in 54\% of patients with foot ulceration and $14 \%$ of patients with neuropathy. Chantelau \& Richter [26] showed that plain radiographs failed to pick up acute Charcot foot and MRI should be preferred for stage 0 acute Charcot foot to prevent progression and deformities.

In the present study, identified cases with Charcot foot underwent follow-up X-rays at 1,3 , and 6 months. Among the 26 cases with Charcot foot, five $(19.23 \%)$ patients showed new changes on Xray at 6 months, when three of them showed mild foot swelling and one patient showed moderate foot swelling; while only one patient showed mild midfoot discomfort. In those patients, MRI studies were performed to ensure a proper management protocol which was total contact cast in four patients and airwalker in one patient. Our findings are in accordance with previous studies, such as Fabrin et al., [11] study, in which $36 \%$ of diabetic patients with Charcot foot had new attacks during follow-up for a median of 48 months. MRI may be crucial since conventional radiographs can appear normal during a very early stage of Charcot disease (Eichenholtz stage 0) [27]. MRI also allows determining the course of the healing process and the success of the offloading treatment [28]. Another important role of MRI is its ability to further evaluate complications of a Charcot foot, in particular soft tissue infections and osteomyelitis [29]

The present study has some limitations. First, the small sample size, which could limit the generalizability of results. Second, our study didn't compare the value of X-ray in comparison with other imaging modalities, such as MRI. Finally, the follow-up duration is limited to 6 months. That we wanted to publish our results so far and we will follow-up the patients for longer period of time to see the outcome.

\section{Conclusion and Recommendations:}

Patients with longstanding diabetes mellitus with no obvious deformity or foot ulcerations should be screened with bilateral foot X-rays to detect early Charcot foot X-ray findings. Positive cases should start offloading and proper foot wear as soon as possibleand they should be carefully followed-up. Also, all patients with longstanding diabetes should be advised about proper glycemic control, avoiding minor trauma and seeking medical advice once early clinical signs of Charcot foot appear.

\section{Ethical approval:}

The study protocol was approved by the ethical committee at our institute. Official permissions and approvalswere obtained prior to data collection. An informed written consentwas obtained from all patients includedinthestudy following guarantee of data confidentiality to them.

\section{Conflict of interest:}

None.

\section{References}

1- ROGERS L.C., FRYKBERG R.G., ARMSTRONG D.G., BOULTON A.J., EDMONDS M., VAN G.H., et al.: The Charcot foot in diabetes. Diabetes Care, 34 (9): 2123-9, 2011.

2- GOUVERI E. and PAPANAS N.: Charcot osteoarthropathy in diabetes: A brief review with an emphasis on clinical practice. World J. Diabetes, 2 (5): 59-65, 2011.

3- ROSSKOPF A.B., LOUPATATZIS C., PFIRRMANN C.W., BONI T. and BERLI M.C.: The Charcot foot: A pictorial review. Insights into imaging, 10 (1): 77, 2019.

4- RAJBHANDARI S.M., JENKINS R.C., DAVIES C. and TESFAYE S.: Charcot neuroarthropathy in diabetes mellitus. Diabetologia, 45 (8): 1085-1096, 2002. 
5- DARDARI D.: An overview of Charcot's neuroarthropathy. J. Clin. Transl. Endocrinol., 22: 100239, 2020.

6- La FONTAINE J., LAVERY L. and JUDE E.: Current concepts of Charcot foot in diabetic patients. Foot (Edinb), 26: 7-14, 2016.

7- MARMOLEJO V.S., ARNOLD J.F., PONTICELLO M. and ANDERSON C.A.: Charcot foot: Clinical clues, diagnostic strategies and treatment principles. Am. Fam. Physician, 97 (9): 594-9, 2018.

8- SMITH D.G., BARNES B.C., SANDS A.K., BOYKO E.J. and AHRONI J.H.: Prevalence of radiographic foot abnormalities in patients with diabetes. Foot Ankle Int., 18 (6): 342-6, 1997.

9- WANZOU J.P.V., SEKIMPI P., KOMAGUM J.O., NAKWAGALA F. and MWAKA E.S.: Charcot arthropathy of the diabetic foot in a sub-Saharan tertiary hospital: A cross-sectional study. J. Foot Ankle Res., 12: 33, 2019.

10- NEHRING P., MROZIKIEWICZ-RAKOWSKA B., MAROSZEK P., SOBCZYK-KOPCIOL A., KRZYŻEWSKA M., PLOSKI R., et al.: Risk factors of charcot neuroarthropathy development in patients with type 2 diabetes. Exp. Clin. Endocrinol. Diabetes, 122 (1): 31-4, 2014.

11- FABRIN J., LARSEN K. and HOLSTEIN P.E.: Longterm follow-up in diabetic Charcot feet with spontaneous onset. Diabetes Care, 23: 796-800, 2000.

12- CHANTELAU E. and POLL L.W.: Evaluation of the diabetic charcot foot by MR imaging or plain radiographyan observational study. Exp. Clin. Endocrinol. Diabetes, 114 (8): 428-31, 2006.

13- YOUNIS B.B., SHAHID A., ARSHAD R., KHURSHID S. and MASOOD J.: Charcot osteoarthropathy in type 2 diabetes persons presenting to specialist diabetes clinic at a tertiary care hospital. BMC Endocr. Disord, 15: 28, 2015.

14- SALINI D., HARISH K., MINNIE P., SUNDARAM K.R., ARUN B. and SANDYA C.J.: Prevalence of Charcot arthropathy in type 2 diabetes patients aged over 50 years with severe peripheral neuropathy: A retrospective study in a tertiary care South Indian hospital. Indian J. Endocrinol. Metab., 22 (1): 107-11, 2018.

15- O'LOUGHLIN A., KELLEGHER E., McCUSKER C. and CANAVAN R.: Diabetic charcot neuroarthropathy: Prevalence, demographics and outcome in a regional referral centre. Ir. J. Med. Sci., 186 (1): 151-6, 2017.

16- SOHN M.W., LEE T.A., STUCK R.M., FRYKBERG R.G. and BUDIMAN-MAK E.: Mortality risk of Charcot arthropathy compared with that of diabetic foot ulcer and diabetes alone. Diabetes Care, 32 (5): 816-21, 2009.

17- KENSARAH A.M., ZAIDI N.H., NOORWALI A., AREF H., MAKKI A.M. and GHUNAIM A.: Evaluation of Charcot neuroarthropathy in diabetic foot disease patients at tertiary hospital. Surg. Sci., 7 (6): 250-7, 2016.
18- FAUZI A.A., CHUNG T.Y. and LATIF L.A.: Risk factors of diabetic foot Charcot arthropathy: A case-control study at a Malaysian tertiary care centre. Singapore Med. J., 57 (4): 198-203, 2016

19- THEWJITCHAROEN Y., SRIPATPONG J., PARKSOOK W., KRITTIYAWONG S., PORRAMATIKUL S. and SRIKUMMOON T.: Salient features and outcomes of Charcot foot-An often-overlooked diabetic complication: A 17-year-experience at a diabetic center in Bangkok. J. Clin. Transl. Endocrinol., 11: 1-6, 2018.

20- SEBASTIAN A.P., DASGUPTA R., JEBASINGH F., SARAVANAN B., CHANDY B. and MAHATA K.M.: Clinical features, radiological characteristics and offloading modalities in stage 0 Acute Charcot's neuroarthropathy - A single centre experience from South India. Diabetes Metab. Syndr., 13 (2): 1081-5, 2019.

21- ERGEN F.B., SANVERDI S.E. and OZNUR A.: Charcot foot in diabetes and an update on imaging. Diabet Foot Ankle, 4: 21884, 2013.

22- WONGDEE K. and CHAROENPHANDHU N.: Osteoporosis in diabetes mellitus: Possible cellular and molecular mechanisms. World J. Diabetes, 2 (3): 41-8, 2011.

23- ABABNEH A., BAKRI F.G., KHADER Y., LAZZARINI P. and AJLOUNI K.: Prevalence and Associates of foot deformities among patients with diabetes in Jordan. Curr. Diabetes Rev., 16 (5): 471-82, 2020.

24- STUCK R.M., SOHN M.W., BUDIMAN-MAK E. and WEISS K.B.: Charcot arthropathy risk elevation in the obese diabetic population. Am. J. Med., 121: 1008-14 2008.

25- VISWANATHAN V., KUMPATLA S. and RAO V.N.: Radiographic abnormalities in the feet of diabetic patients with neuropathy and foot ulceration. J. Assoc. Physicians India, 62 (11): 30-3, 2014.

26- CHANTELAU E.A. and RICHTER A.: The acute diabetic Charcot foot managed on the basis of magnetic resonance imaging--a review of 71 cases. Swiss. Med. Wkly, 143: w13831, 2013.

27- MAUTONE M. and NAIDOO P.: What the radiologist needs to know about Charcot foot. J. Med. Imaging Radiat. Oncol., 59 (4): 395-402, 2015.

28- RENNER N., WIRTH S.H., OSTERHOFF G., BÖNI T. and BERLI M.: Outcome after protected full weightbearing treatment in an orthopedic device in diabetic neuropathic arthropathy (Charcot arthropathy): A comparison of unilaterally and bilaterally affected patients. BMC Musculoskelet Disord., 17 (1): 504, 2016.

29- TOLEDANO T.R., FATONE E.A., WEIS A., COTTON A. and BELTRAN J.: MRI evaluation of bone marrow changes in the diabetic foot: A practical approach. Semin. Musculoskelet. Radiol., 15: 257-68, 2011. 


\section{قدم شاركوت قبل ظهور الآعراض الإكلينيكية فى مرضى السكر افترات طويلة}

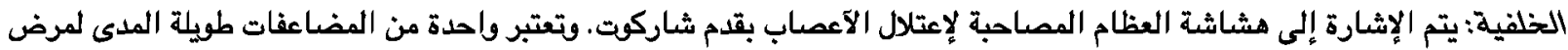

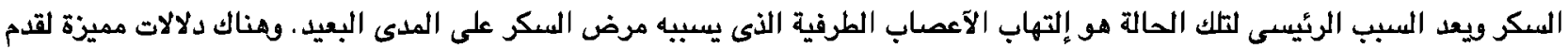

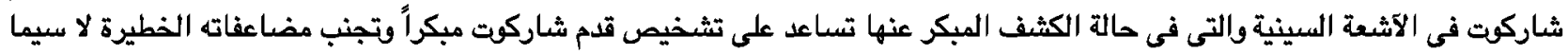

الهدف: تشخيص قدم شاركوت قبل ظهور آعراضه الإكلينيكية في مرضى السكر لفترات طويلة وتقليل نسبة حلوث مضاعفاته الخطيرة لا سيما البتر.

المرضى وطرق البحث: هذه دراسة مستقبلية لتقييم مدى فاعلية الآشعة السينية فى الكثف المبكر عن قدم شاركوت قبل ظهوف آعراضه

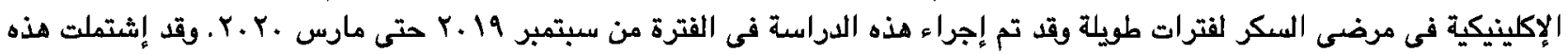

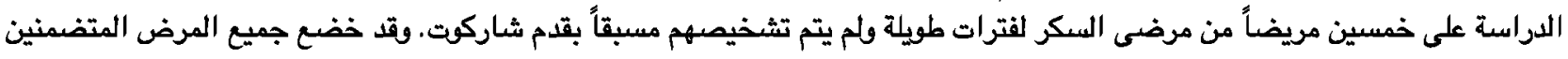

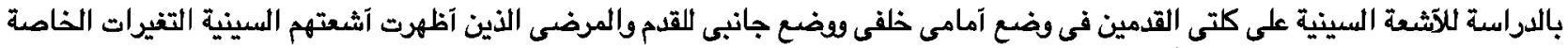

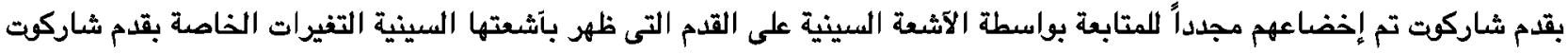

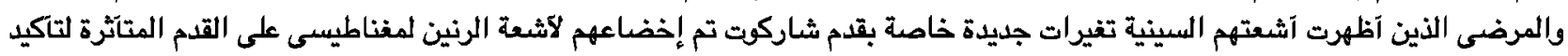
التشخيص وتصديد طريقة العلاج اللازمة.

النتائج:وقد آظهرت النتائج آن ستة وعثرين من الحالات قد ظهر باتشعتهم التغيرات المميزة لقدم شاركوت ومن ثم تمت متابعتهم بآثعة

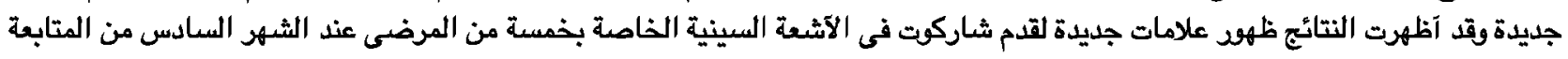

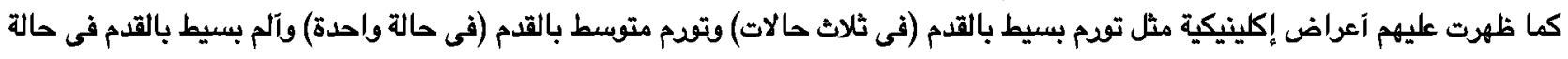

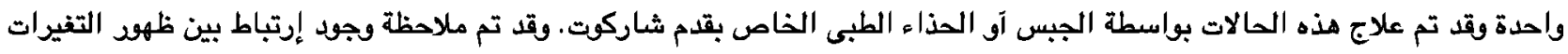

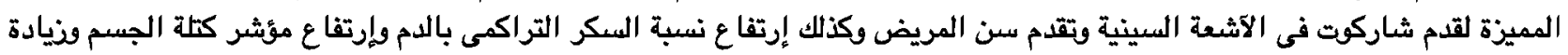

مدة مرض السكر عند المريض.

الخلاصة: كشفت الدراسات آنه يجب عمل الآشعة السينية بشكل دوىى على القدمين في مرضى السكر لفترات طويلة الذين لا تظهر عليهم

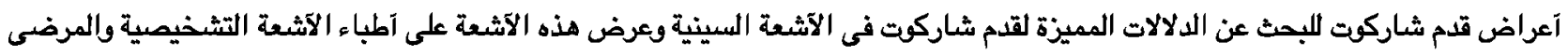

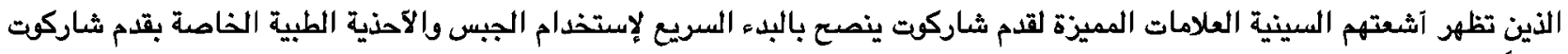

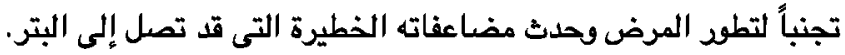

